\title{
THE JOURNALIST'S COMMUNITY AND ETHICS CODE IN INDONESIA
}

\author{
Sika Nur Indah \\ Universitas Pembangunan Nasional Veteran Yogyakarta, Indonesia \\ sikanurin@upnyk.ac.id
}

\begin{abstract}
$A$ violation of ethics code reported by some journalists shows that there is a problem in the journalistic ethics code. This research aims to find out the role of journalists community in influencing the knowledge of journalistic ethics code. This qualitative research method done by interviewing some of reporters in Solo, Central Java, Indonesia. The results showed two supportive community groups that support Indonesian journalist code of ethics, Kode Etik Wartawan Indonesia (KEWI) and also did not support it. The first group will help the role of press companies and organisations in providing the knowledge of journalistic ethics code. Meanwhile, the second group maybe will blockage the role of press companies and organisations in providing the knowledge of journalistic ethics code Thus community will becomes one of the important factor for journalists in learning and gaining the knowledge of journalistic ethics code, outside the press company and the press organization.
\end{abstract}

Keywords: ethics code, journalist's community, journalistic ethics

\begin{abstract}
Abstrak
Adanya laporan pelanggaran kode etik oleh sejumlah wartawan menunjukkan adanya permasalahan etika di dinia jurnalistik. Penelitian ini bertujuan untuk mengetahui peran komunitas wartawan dalam mempengaruhi pemahaman kode etik jurnalistik. Penelitian dilakukan dengan metode kualitatif dengan mewawancarai sejumlah wartawan media cetak di Kota Solo. Hasil penelitian menunjukkan dua kelompokkomunitas yang mendukungdan kelompok komunitas yang tidak mendukung pemahaman wartawan terhadap Kode Etik Wartawan Indonesia (KEWI). Kelompok pertama akan membantu peran perusahaan pers dan organisasi pers dalam memberikan pemahaman etik jurnalistik kepada wartawannya. Kelompok kedua justru akan memperberat peran perusahaan pers dan organisasi pers. Dengan demikian komunitas menjadi salah satu faktor penting bagi wartawan dalam belajar dan memperoleh pemahaman tentang kode etik jurnalistik, di luar perusahaan pers dan organisasi pers.
\end{abstract}

Kata kunci: Etika Jurnalistik, Kode Etik, Komunitas Wartawan. 


\section{Introduction}

The Indonesian press grew rapidly after the post-government of the New Order rezim. The publication of Undang-Undang No 40/1999 about the press became the guarantee of press freedom in Indonesia. The threat will no longer exists. This matter supported by the publication of Surat Keputusan No. 132/1998, which makes it easier for anyone to have the press release business license.

The chairman of Indonesia's Press Council - Dewan Pers - Yosep Adi Prasetyo during the commemoration of the National Press Day in Padang in 2018 mentions that there are currently 47,000 mass media in Indonesia. Of these 2,000 are print media, 674 radios, 523 televisions and online media (tempo.co). Unfortunately this condition is not balanced with the quality improvement of press companies that put forward the function and professionalism of the press.

Dewan Pers in first semester 2017 noted that there were 600 public complaints about alleged journalistic code violations. This amount increased from the previous year that reaching 800 complaints for one year. The domination of alleged infringement is done by online media (antaranews.com).

This data indicates if the application of journalistic ethics is still an issue. Journalists have not fully understood and implemented the journalistic ethics code, Kode Etik Wartawan Indonesia (KEWI). In fact, KEWI is the foundation for journalists's profession. This lack of knowledge is due to several factors, including the high workload and quantity of news. Especially for online media that boasts a considerable speed, prone to plagiarism (Sularto, 2007).

Accuracy problems become vulnerable due to the emergence of cut and paste culture. The high workload has not been balanced with good welfare. According to a survey conducted by Aliansi Jurnalis Independen (2010), there are still many journalists in small press companies who earn 
small wages. This condition raises the insecurity of independence and imbalances in news production.

Ethical and moral issues related to good or bad judgment. In journalistic, Carol Marlin reveals the absence of law about the news. It depends on the guiding compass to do or not to do something. The moral dimensions was given strong attention by journalist profession to determine the grey area of ethical decision (Kovach, 2001). Incomprehension journalists to the code of ethics can even lead to legal issues (Manan, 2011).

The press business is a trust business. The press without such beliefs lost the spirit of social life. Knowledge and understanding of Undang-undang No 40/ 1999 and KEWI is required to maintain public trust (Nugroho, 2011). This is the reason why the ethical elements in journalistic need to be examined. Moreover, journalists in this case reporter are the spearhead of the news. Lack of ethical understanding will affect the quality of preaching, which will eventually impact the public trust in the press performance.

Solo, Central Java was chosen as a sample to the city that become the birthplace of the press. In addition, the growth of press business in Solo is dynamic with many media that was born and died in this city. In addition to local media, some national media both print, television and online put contributors in Solo City. Until 2019 there were at least five media offices in the city of Solo, namely TATV, Solopos, Suara Merdeka, Radar Solo, and Kompas group.

Based on previous research, a journalistic violation case has also been revealed in Solo. Research conducted by the research team of Tim Riset Klinik Hukum Media Adma Jaya Yogyakarta found that the data violations code conducted by one of the newspapers related to the Surakarta Palace conflict (Bonaventura, 2016). Sanctions dismissal has been done media Solopos because the reporter made the news of lying 
and also to the media Harian Joglosemar because the reporter received a bribe (Indah, 2016).

The research was developed from a previous study titled Local Press and Journalistic Ethics (2016). In a previous study, the results of journalistic knowledge of print media journalists in Solo have not been maximized. This was influenced by the role of press companies, press organizations and the social environment that also did not provide maximum journalistic ethics (Indah, 2016).

This study more specifically discusses how the journalist community in Solo affects the understanding of ethics code. The reason in conducting journalistic work, intertwined interaction between one journalist and the other because of the similarity of interest in covering certain events or issues. From this interaction brings together a group or community of journalists who are common to the joint.

\section{Research Question}

The focus on the study is through this question: How the journalist's community in Solo, Central Java, Indonesia was instrumental in encouraging an understanding of Indonesian journalist code of ethics, Kode Etik Wartawan Indonesia (KEWI)?

\section{Literature Review}

Based on Undang-undang No 40/ 1999, the press interpreted as a social institution and the mass communication rides that carry out journalistic activities include finding, acquiring, owning, storing, processing, and conveying information either in writing, sounds, images, sounds and images, as well as data and graphics or other forms using printed media, electronic media and any type of channels available.

The role of the press based on such legislation meets the rights of society to obtain information, uphold the fundamental value of 
democracy, develop a general opinion based on accurate information. In addition, it conducts surveillance, criticism and advice on issues relating to public interest as well as the fight for justice and truth.

This is in line with the theory of social responsibility of the press. According to this theory the press has a social responsibility to the community or in other words the freedom of responsibility to the community (Siebert,1986). Nevertheless in his travels so many things have been done press so that makes it far from social responsibility and professionalism.

Paul Johnson (1994) in his article What's Wrong with the Media and How to Put it Right mentions that there were seven things he called a media sin that made him far from social responsibility and professionalism. (1) Distortion. These points can happen through an excessive editing process that leads to certain tendencies. (2) Fake image. The Media intentionally creates stereotype images to describe a particular event that cannot be explained through photos or videos. (3) Privacy theft. Often media bias in the preaching of a person's personal life is not in line with the public interest. (4) Character killings. This is prone to if the media is not precisely targeted aiming (target audience). (5) Exploitation of sex. Media uses pornography as a tool to increase ratings and circulation. (6) To contaminate the children's minds. The content that the media presented has a bad impact on children's minds. (7) Misuse of media power. The Media is used as a tool to change people's attitudes and behaviour by a particular interest group.

To avoid such sins, the media must have ten moral rules, primarily at the level of policy-makers. The moral problem becomes an important thing because to be a professional required good moral (Johnson, 1994).

The ten recommendations include journalists who must have the primary desire to find and tell the truth, journalists should always think about the consequences of what he says, journalists should be educated 
to be able to make good judgments, have responsibilities (the soul of leadership). The next points of the media should have a leadership soul and journalists should have the urge to educated (missionary spirit). A moral medium performs dialogue with the community and avoids emotional attitudes, applying justice, willing to admit mistakes as well as understanding the "words" can kill in a variety of ways.

Moral speaking is always associated with ethics. Both of them have different understanding although interchangeable. Moral talks about true and false standards that are practical, specific and based on a culturally shared agreement. While ethics is a general and systematic study of everything that is a true and false principle(Johansen, 1998). Contemporary humanist rhetoric W Ross Winterowd says ethical responsibilities, not a matter of goodwill. Ethical responsibilities base themselves on the honest handling of the matter and the influence of knowledge (Johansen, 1998).

Ethical and moral issues are still being discussed, including in the media field. Bill Kovach (2001) In his description introduces nine journalistic elements that journalists should do. (1) The first obligation of journalism is on the truth, (2) The first loyalty of journalism is to the community, (3) Digest of Journalism is a verification, (4) Journalism practitioners must maintain independence to news sources, (5) Journalism must be a power monitor, (6) Journalism should provide criticism and community support forums, (7) Journalism must strive to make matters interesting and relevant, (8) Journalism should broadcast comprehensive and proportional news, (9) Practitioners of journalism should be allowed to follow their conscience

Long before this, attention to the ethical problems of journalists has existed since the 20th century. Joseph Pulitzer when establishing a journalistic school reveals the importance of ethical elements in journalists 's work. It is the moral responsibility that will save journalism from adherence to business interests in opposition to the community's welfare 
efforts (Kertopati, 1981). The birth of the professional ethics code is also born a decree on the black above the white intention of a profession to manifest moral values. In other words, the ethics code should be the result of self-regulatory of the profession.

In Indonesia, the code of ethics for journalist's profession is contained in Dewan Pers rules No 6/Peraturan-DP/V/2008 on the ratification of Dewan Pers No. 03/SK-DP/III/2006 concerning the code of journalistic ethics as Dewan Pers's rules. More specifically, each journalist organization has its own ethics code, such as Aliansi Jurnalis Independen and Persatuan Wartawan Indonesia. Referring to the ethics code issued by the press board or also known as Kode Etik Wartawan Indonesia (KEWI), there are 11 chapters that govern how Indonesian journalists should work.

In carrying out his profession, journalists always interact with their fellow profession friends. Community according to Ralph Linton is a group of people who live and work together long enough, so it can govern themselves and consider themselves as a social unity with clearly formulated boundaries (Bungin,2008).

While in the communication the term community or community at least refers to five understandings (Littlejohn, 2009). The first community is used to describe a set of people who inhabit certain haha. Second, the community is a group of people who share cultural identities. Third, the community is a set of people who share certain interests or activities. In the fourth sense, the community is understood as a positive sentiment that may be enforced, accomplished, pursued, or almost extinct that takes place within a group or organization. Lastly, the community is two interdependent political poles while having tension between the two.

Jean Lave and Etienne Wenger in Littlejohn (2009) identify the community in a discrete unit as a community of practice. The practice community refers to a group of people who share goals and pursue 
goals alike. Generally, everyone is a member of the practice community. Whenever people come in a group to do the same, for example in working groups, class groups, leisure or political groups, they are essentially involved in a community of practice.

Chart 1, Mine Frame

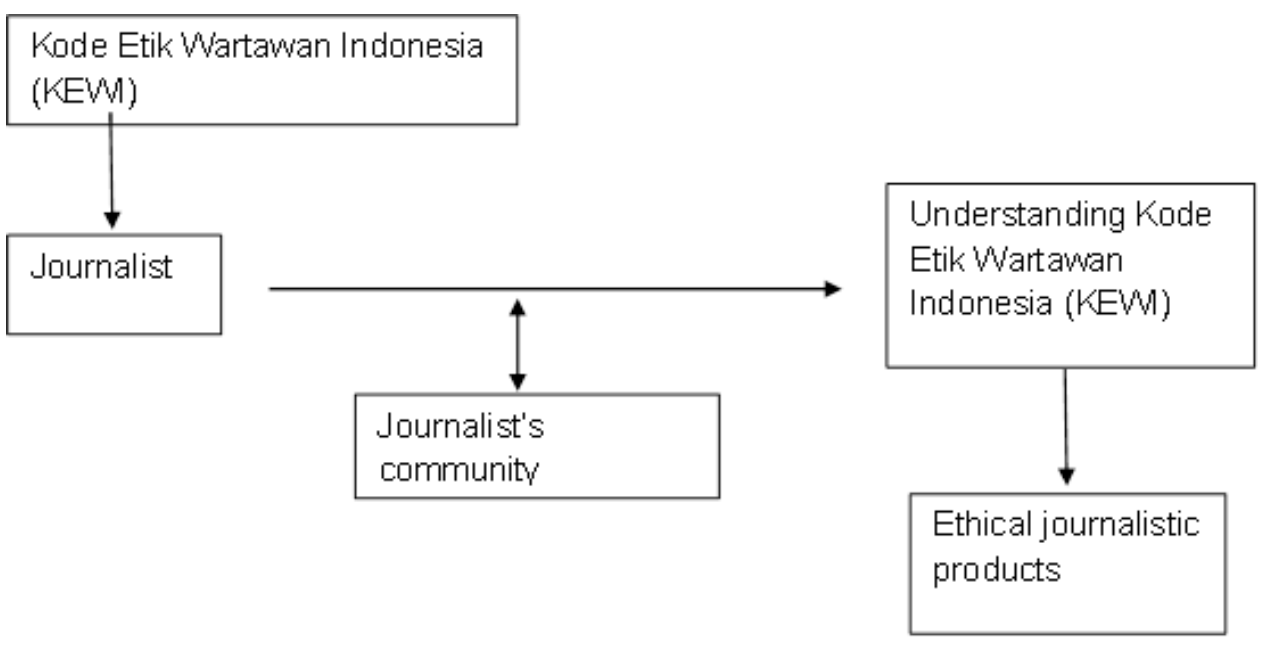

\section{Research Methods}

The problem formulation in this study is answered by qualitative methods. The detailed data in qualitative research was analyzed to give an overview of the objects examined through the collected samples prior to withdrawal of the publicly available conclusions (Sugiyono, 2009).

A sample or research subject is a print media reporter in Solo. Selected samples with purposive technique or sample aiming. This technique considers several things to capture accurate information of research data (Sutopo, 2002). Furthermore, in this study the third data collection techniques that are participation, observation and interviews will be done to get as much data as possible in answering the problem formulation. To add data, will be used documents, journals and books related to research topics. 
Data validity is checked by using data/source triangulation and method triangulation. Triangulation is done by looking from a diverse perspective so that the data is obtained more complete and convincing for the withdrawal of conclusions (Sutopo, 2002).

Data analysis is conducted based on an interactive analysis model consisting of three main components namely data reduction, data presentation and withdrawal conclusion (Miles and Huberman, 1994). Based on this model, the three components are not linear processes but are cycles. That is, of all the data obtained by researchers conducted the selection and grouping of data. Data that is assessed as inappropriate is discarded as a data reduction process. While the corresponding data is retained as a data serving process for the then drawn conclusions. Nevertheless, this process does not stop at this stage, to get a valid conclusion, it is possible to reduce and representation the data.

\section{Discussion}

Being a journalist, someone faces working consequences not knowing the time. It does not mean 24 hours a day without ceasing, but it must be ready 24 hours when the call of duty comes. Another thing to face is the deadline. Each media applies different targets and deadlines for each reporter. For online media, for example, deadlines are usually faster. An event must already be reported or displayed in the media shortly even as the event progresses. This is different from the print media with the format of a daily newspaper that is relatively constant - in the afternoon or before the print.

That overview is also happening in Solo. In carrying out its duties, journalists are very rare, except for the special assignment of the company in which he is engaged. Generally an event is covered together by many journalists from various media. Starting from the same interests in finding data and facts on the field, interactions take place intensively. From the 
unacquainted to being familiar with the intertwined personal closeness.

The community that exist in Solo are Komunitas Dewan, Komunitas Ekbis, Komunitas Pendidikan, Komunitas Balaikota, Komunitas Cemoro dan Komunitas Yahoo. Community is formed because of the similarity desk coverage, such as Komunitas Dewan is a community of journalists who have the task of controlling political and legislative issues, Komunitas Ekbis is a collection of economic and business journalists, Komunitas Pendidikan consisting of those tasked with controlling the education issue in Solo, Komunitas Balaikota formed because of the task of having a coverage in the government center - Balaikota Solo. Komunitas Cemoro contains journalists who have the task of controlling legal and criminal issues. The name Cemoro is taken from the place where the community is commonly gathered. This is the same with Komunitas Yahoo which is where television journalists are gathered. In this location (Yahoo) journalists commonly do image editing before sending it to the media where they work to serve.

The community that was born from the similarity of this coverage desk became the second office. Much time is spent together in this community. Interwoven interactions are not only a matter of work such as sharing the agenda of coverage, but also leading to interpersonal relationships. To the author, some respondents acknowledged the creation of a family bond in the journalist community in Solo. Interpersonal relationships are closely aligned with the intensity of interactions in the community. They commonly spend time working together. Some even choose not to return to the office but instead finish the job at the location where the community gathers. Comfort is one of the reasons. Therefore it is not surprising if the gathering location is almost always crowded, even for certain communities until late at night. This means that the interactions that take place among community members are quite intense.

The comfortable atmosphere that is felt by the community members 
is not separated from the interaction which not only concerns the work of the cutting edge also leads to personal affairs. If there is one member or family of a sick community, for example, another member will be moved to a visiting visit. Another example, to spread the iftar together during Ramadan, recreation together or simply hanging out together while chatting to relieve fatigue due to work.

Interactions in the community form habits that develop into a community culture. Newcomers inevitably have to adapt and conform to the culture of the community, including how the profession works. Those who do not want to follow the "rules" will be eliminated. That is, it is possible to access agenda information coverage will be closed. The reason is that interviewings have a tendency to spread information on one or more members of the community.

In terms of journalistic work, the community culture also affects how its members perceive the profession code of ethics. Of the 11 chapters contained in Kode Etik Wartawan Indonesia (KEWI) can be extracted into three important points that are knowledge; integrity; rights and obligations. This division is in line with the grouping of Persatuan Wartawan Indonesia (PWI) ethics code.

Tabel 1 Kode Etik Wartawan Indonesia

\begin{tabular}{ll}
\hline Knowledge \\
\hline Chapter 3 & $\begin{array}{l}\text { Indonesian journalists are always testing the information, } \\
\text { preaching in a balanced, not mixing facts and judgmental } \\
\text { opinions, and applying the principle of presumption of } \\
\text { innocence. }\end{array}$ \\
\hline Chapter 4 & $\begin{array}{l}\text { Indonesian journalists do not make news of lying, } \\
\text { defamatory, sadistic, and obscene. }\end{array}$ \\
\hline Chapter 5 & $\begin{array}{l}\text { Indonesian journalists do not mention and broadcast the } \\
\text { identity of victims of moral crimes and do not mention } \\
\text { the identity of children who become criminals. }\end{array}$ \\
\hline
\end{tabular}


Chapter 8

Indonesian journalists do not write or broadcast news based on prejudice or discrimination against a person on the basis of differences in tribe, race, color, religion, gender, and language and do not degrade the weak, poor, sick, Disability or physical disability.

\begin{tabular}{ll}
\hline Chapter 1 & \multicolumn{1}{c}{ Integrity } \\
& $\begin{array}{l}\text { Indonesian journalists are independent, producing } \\
\text { accurate, balanced, and not bad-faith news. }\end{array}$ \\
\hline Chapter 2 & $\begin{array}{l}\text { Indonesian journalists undertake professional ways to } \\
\text { carry out journalistic tasks. }\end{array}$ \\
\hline Chapter 6 & $\begin{array}{l}\text { Indonesian journalists do not misuse professions and do } \\
\text { not accept bribes. }\end{array}$ \\
\hline
\end{tabular}

\section{Rights and Obligations}

Chapter 9 Indonesian journalists respect the rights of their personal life, except for the sake of the public.

Chapter $10 \quad$ Indonesian journalists immediately revoke, rectify, and correct erroneous and inaccurate news accompanied by apologies to readers, listeners, and or viewers.

Chapter 11 Indonesian journalists serve proportional rights and correction rights.

Chapter 7 Indonesian journalists have the right to refuse and protect the speakers who are unwilling to know their identity or existence, respecting the provisions of embargo, background information, and off the record in accordance with the agreement.

The existence of a community that is closely related to journalistic work practices is often utilized by journalists in Solo as a place to study. The bonding of family ties to create a comfortable atmosphere, becomes one of the options for junior journalists to learn from his seniors about journalistic work. A number of respondents the authors encountered acknowledged this. Especially when it gets new tasks from the office where they work, usually many new terms or new issues that should quickly be learned, such as from the criminal law desk to economics desk, from education to politics desk, from economics to sports desk, and so on.

In addition to petrifying the rhythm of work at the new desk, the community is also a place to learn technical news writing for those 
who are new to plunge into this profession. Because some media in Solo implemented the learning by doing system. Media companies directly hit new journalists into the field without giving advance training. In other words, new journalists are asked to learn while plunging into the field directly. Some respondents admitted often getting guidance from his seniors in the community about technical ways of writing news, about what can and shouldn't be featured in the news.

In matters of journalistic work, seniors have an important role in the journalists community in Solo. Those deemed seniors usually have more power to control members of a more junior group. The reason seniors with experience - is assessed to have a better network to access news sources. Although not all seniors definitely have a network and enough power to be a group leader.

This learning includes understanding journalists to professional ethics, primarily for new journalists. For those who join a press company that relies on the learning by doing system, understanding Kode Etik Wartawan Indonesia (KEWI) is only obtained half-half. Especially if they do not join the existing journalists' professional organizations, such as Persatuan Wartawan Indonesia (PWI), Aliansi Jurnalis Independen (AJI), Asosiasi Jurnalis Televisi Indonesia (IJTI), Pewarta Foto Indonesia (PFI) and etc.

The problem is, the social environment does not necessarily support this issue. Muhammad Rofiuddin (2011) in his research shows the environment gives a strategic role to the still suburban envelope culture (bribery/gratification) in the journalist's neighborhood in the city of Semarang. In Solo, there are several terms that are synonymous with gratuities including Amplop, Uang Bensin, 86 and Suel. There is no possibility for some speakers to provide special money for journalists who do the coverage. For example, related product launches, new establishments, educational institutions, legal cases, including political 
agendas conducted by political parties.

In the case of a gratuity that is clearly contained in the KEWI, the community has an important role in influencing journalists understanding. If the majority of members consider the granting of the resource not a gratification this will develop into a general view that allows the "gift" to be accepted. If there are members of the community who refuse, must be prepared to receive an unpleasant satire from other community members.

In terms of technical news making, the community doesn't always give a positive impact. One of its indication is the emergence of copy and paste practice. This practice arose because the journalists who gathered in the community exchanged the news. As a result, it is not surprising that when news aired in the media looks very similar, both from the viewpoint and groove. For those who are not adequately equipped with knowledge of professional ethics, can slip in plagiarism. This issue is also prone to legally sued if the written content is problematic.

A close family comfort and bonding become the cause of copy and paste practices to grow in the community. Those who are absent can also easily make news because there is a practice of exchanging news. In some cases the available coverage materials are still raw data, for example the interview data in the form of a speaker record. Members of the community who are not present, can make news from the raw materials circulating in the group WhatsApp community.

With respect to speakers, information from the community can make it easier or provide alternatives for enriching news. The community's view of credibility and competency is also a matter of consideration for a journalist. On the other hand, the community also influenced the selection of speakers. For example, for the issue of a five-day school enforcement policy, journalists who are members of the education journalists community will discuss to search for resources that are assessed as suitable for the issue. 


\section{Conclusion}

The understanding of a journalist against the ethical profession is influenced by several things, one social environment. The social environment as intended is a place or situation where journalists interact with each other because of the similarity of purpose, i.e. looking for coverage data. From the intense interaction, the community formed. In Solo, the community is formed as a "home" in journalistic work. Like a home, family ties are firmly formed in them. The bond formed at the same time affects how journalists work, including an understanding of professional ethics.

Kode Etik Wartawan Indonesia (KEWI) consisting of 11 chapters, was born to be a guideline for journalists in carrying out their profession. Although not all chapters have an association with the role of community in providing the understanding of KEWI, but not to be denied the influence of the community on competence, integrity and understanding of the rights and obligations of a journalist.

It is important for every individual journalist, especially those who are new to plunge into this profession to understand professional ethics. It is usually learned from the press companies where they work as well as press organizations as a professional container of journalists. But seeing strong ties in the community makes this informal container also an important role in understanding the code of ethics. A good community will support its members to gain the understanding of journalistic work according to professional ethics. On the contrary, there are still communities lacking in support of this issue. Without the basic understanding of professional ethics, journalists will easily carry the flow of communities that are actually not in line with the spirit of KEWI. 


\section{Bibliography}

Bungin, Burhan. 2008. Sosiologi Komunikasi.Jakarta: Kencana

Griffin, EM. 2009. A firms Look at Communications Theory Sevent Editions,

New York: Mc Grow Hill.

Johansen, Ricard L. 1998. Etika Komunikasi. Bandung: Rosda Karya Kasmadi dan Samsuri. 2010. UU Pers dan Peraturan-peraturan Dewan Pers.

Kertopati, Ton. 1981. Dasar-Dasar Publisistik, Jakarta: Bina Aksara.

Kovach, Bill \& Tom Rosenstiel. 2001. Penerjemah Yusi A Pareano. Sembilan Elemen Jurnalistik. Jakarta: Pantau.

Littlejohn, Stephen W dan Karen A Foss. 2009. Theories of Human Communication Ninth Editions, Thomson Wardword.

Manan, Bagir. 2011. Menjaga Kemerdekaan Pers di Pusaran Hukum. Jakarta: Dewan Pers.

Manna, Abdul. 2010. Upah Layak Jurnalis (Survey Upah layak AJI di 16 Kota di Indonesia). Jakarta: Aliansi Jurnalis Independen.

Miles, Mathew B \& A Michael Huberman. 2014. Penerjemah Tjetjep Rohendi Rohidi. Analisis Data Kualitatif. Jakarta: UI Press.

Seri Pustaka Yustisia. 2005. Hukum Jurnalistik. Yogyakarta: Pustaka Widyatama.

Siebert, Fred S \& Theodore Peterson, Wilbur Scharm. 1986. Empat Teori Pers. Alih bahasa Putu Laxman Sanjaya. PT Intermasa.

Sugiyono. 2009. Metode Penelitian Kuantitatif, Kualitatif dan R\&D, Bandung. Sularto, St. 2007. Kompas Menulis dari Dalam. Jakarta: Kompas.

Sutopo, HB. 2002. Metodologi Penelitian Kualitatif: Dasar Teori dan Penerapannya dalam Penelitian, Surakarta: Sebelas Maret University Press.

Tim Aji Semarang. 2014. Potret Intervensi di Bilik Redaksi. Semarang Tim PWI. 2001. PWI 55 Tahun: Menegakkan Profesionalisme dan Etika Pers di Era Multimedia, Jakarta.

Wibowo, Wahyu. 2009. Menuju Jurnalisme Beretika. Jakarta: Kompas 


\section{Journals and Internet Articles}

Antara. 2018. "Terungkap, Indonesia Punya Media Massa Terbanyak di Dunia". https://nasional.tempo.co/read/1059285/terungkapindonesia-punya-media-massa-terbanyak-di-dunia $/$ full\&view=ok. Diakses Juni 2019

Bekti Nugroho. 2011. Jurnal Dewan Pers. Profesionalisme, Sejarah dan Masa Depan Pers Daerah. Edisi No 5 Mei 2011

Bonaventura Satya Baratha. 2016. Praktik Jurnalistik Indonesia, Diskripsi Kasus-kasus Pelanggaran Hukum dan Etika dalam Realitas Jurnalistik Indonesia. Materi Lokakarya KHM UAJY 19-20 Februari 2016.

Fazar Muhardi dan Vera Lusiana. 2017. "Dewan Pers: Jurnalis Langgar KodeEtikMeningkat". https://www.antaranews.com/berita/648173/ dewan-pers-jurnalis-langgar-kode-etik-meningkat. Diakses Juni 2019.

Paul Johnson. 1994. "What's Wrong with the Media and How to Put it Right." AEI Bradley Lecture Series. www.aei.org.

Sika Nur Indah, 2016. Pers Lokal dan Etika Jurnalistik (Studi Deskriptif Tentang Penerapan Kode Etik Jurnalistik Wartawan Media Cetak Di Kota Solo). Thesis. Surakarta: Universitas Sebelas Maret. 
INJECT (Interdisciplinary Journal of Communication), Vol.4, No.2, Des. 2019: p. 219-236

this page intentionally left blank 